\begin{tabular}{|c|c|}
\hline & Asian Social Work Journal (ASWJ) \\
\hline $\begin{array}{c}\text { ASIAN SOCIAL WORK } \\
\text { SOURAL } \\
\text { (ASW) }\end{array}$ & Volume 4, Issue 1, February 2019 \\
& e-ISSN : $0128-1577$ \\
& Journal home page: \\
& www.msocialwork.com \\
\hline
\end{tabular}

\title{
Analysis of SocialCultural Factors Influence to the Children in Conflict with Law: A Case Study in 3 Regencies and Municipality of Bengkulu Province, Indonesia
}

\author{
Sri Putri Permata ${ }^{1}$, Muria Herlina ${ }^{1}$ \\ ${ }^{1}$ Department of Social Welfare, Faculty of Social and Political Sciences, University of Bengkulu \\ Corrrespondence: Sri Putri Permata (sriputri_jar0703@yahoo.com)
}

\begin{abstract}
This research aimed to analyze sociocultural factors among children in conflict with law in the villages of 3 regencies and 1 municipality in Bengkulu Province. Data were collected through observation, in depth interview as well as documentation study. 15 peoples was selected as informants which consist of 6 formal and informal leaders, 6 children in conflict with law, 2 parents, and a social worker. This research finding showed that in the villages most villagers were farmers who spent almost all day for work. This impacted in decreasing time to interact with their children and surrounding neighbors. On the other side, social control were growing weaken. It was indicated by degradation of sociocultural as well as religious values in community. Social status was valued from one's belonging. Normative customary sanctions were not implemented strictly anymore. Both formal and informal leaders practiced bad behavior. Impact of technology such as uncontrolled use of smart phone had negative impact to the juvenile. This research concluded that there were some changes in sociocultural values which interacted in case of children in conflict with law. From this finding, the efforts to strengthen family functions were needed besides optimizing the roles of law, customary and religious institution as well.
\end{abstract}

Key words: children, conflict with law, socialcultural, family, leader

\section{Introduction}

Children who are faced with the law is a child who has reached the age of 12 but has not reached the age of 18 years and is not married, who is suspected, suspected, charged or convicted of committing a crime, being a victim of a criminal act, and/or being a witness to a criminal act (Ministry of Social Affairs, 2014).

In 2008, there were 6505 cases of children in conflict with law. This number increased to 6704 children in 2009. The number of all child cases may be much greater because the figure only comes from 29 Correctional Centers (BAPAS) that have provided reports, while the total number of BAPAS in Indonesia is 62 . In 2013 there were 1121 cases of children in conflict with law and increased to be 1851 cases in 2014. (Ministry of Social Affairs, 2015).

In Bengkulu Province, children in conflict with law is also an important problem which should receive serious attention. It is still fresh in our minds how the public was struck by the rape of Yuyun. This case occurred in the Rejang Lebong Regency of Bengkulu Province. In that event, Yuyun was raped by 14 teenagers who were drunk from drinking liquor. Yuyun's case only represents a number of cases 
which should arouse public awareness that the children in conflict with law is very important problem to be solved.

Based on data from the Bengkulu Province Social Welfare Office, over the past 2 years, there were 181 cases of children in conflict with law in Bengkulu Province. Of the 181 cases that occurred, 34 children were the actors while 147 children were the victims. ( Office of Social Welfare, February 2018). Based on these data, it can be said that the phenomenon of children in conflict with law in Bengkulu Province is a very important issue to be handled. Allegedly, children in conflict with law has also become an iceberg phenomenon, meaning that more cases may occur than reported.

Various changes that occurred in the community such as shifts in values, norms and culture and the negative impact of technology are thought to be related to the increasing cases of children in conflict with law. Most of all research on children in conflict with law study the cases from its legal aspects. Meanwhile, there is only 1 study that examines in terms of social aspects, namely family care. So far, there has been no research in term of various factors that cause children in conflict with law. In connection with this, the analysis of the sociocultural factors that interact with the occurrence of children in conflict with law cases in Bengkulu Province is important to study.

\section{Literature Review}

Children/adolescents are the next generations of the nation because when they grow up they will become leaders, replacing the current generation. Thus, creating a good environment and education becomes very important for the continuity of child development. Children who grow physically, mentally and psycho-socially healthy will someday become qualified human resources, as the successors of nation-building.

Related to the development of children/adolescents it can be said that in this period there were various changes both in terms of physical, cognitive and social-emotional. As a result of various changes that occur in children/adolescents, that physical, psychological and emotional conditions are very volatile and even explosive. In dealing with these situations, the role of the family, especially parents, becomes very important.

The family is the first environment known to children so that the effect will be very large on their development in the future. In accordance with the theory of social learning, that child will learn to behave through his imitation of an environmental $\mathrm{n}$. Thus, the role of attitudes, and behavior of parents have a great influence on the formation and development of children's personality. The development and personality of children can be seen from the independence and social behavior of children in everyday life.

In the family, parents play a major role in nurturing and educating children to behave in accordance with the values and norms that applied society. In addition, because childhood and adolescence is an important period in the process of physical growth and development of mental and psycho-social. Childhood is also a period of instability or is known primarily from the emotional aspect so that it is also called the identity search period. In the process of growth and development, the role of parents becomes very important.

However, in reality, the parenting process is not always in line with expectations. Parenting is often tinged by things that sometimes do not support the independence of children. These include attitudes and behavior of parents which should not be imitated by their children, uncontrolled emotions, as well as bad interaction between parents and children (Astuti, 2011).

According to Shanti (in Astuti, 2011) parenting is a pattern of interaction between parents and children, namely how parents' attitudes and behavior when interacting with children, including how to apply rules, teach values/norms, give attention and affection and foster attitudes and good behavior so that it can be an example for his child. According to Prasasti (2010), generally antisocial children come from 
broken home families . Children are formed in such a way from their parents' upbringing. Parents who have never taught social norms or good values will make their children tend to break the rules. On the other hand, Clemes (2001) argues that the occurrence of child behavior deviations is caused by lack of dependence between parents and children. This happens because between children and parents are never the same in everything. This dependence of children on parents can be seen from the desire of children to obtain protection, support, and care from parents in all aspects of life. In addition, the children who offend the rule sis a problem is likely to occur as a result of the malfunction of the social system in his neighborhood. In other words, children's behavior is a reaction to their environment. The environmental factors such as the advancement of information technology and globalization that are developing rapidly now greatly affect the values and norms that apply to individuals, families, and society. This can result in various social problems in children such as violence, theft, sexual harassment, brawls and others that cause children in conflict with law (Astuti, 2011).

Watching trends in the media today, both print and electronic media, the number of criminal acts committed by children is increasing. This problem is an increasingly complex problem and needs to be addressed by both the government and the community. According to Atmasasmita (in Soetodjo, 2006), there are extrinsic and intrinsic motivations in cases of juvenile delinquency. Intrinsic motivation are intelligence, sex, and the position of children in the family while extrinsic motivation refers to the social environment that is household, school, peers, neighbors and the influence of mass media.

The social environment is one of the factors that can influence a person's behavior. The social environment is the interaction between the community and their environment. Dalyono (2010) argues that the social environment includes friends, neighbors, and society. In social life, there are good relationships and those that are not good. A good association has a positive influence on the development of one's personality. Conversely, bad relationships will have a negative impact on themselves and others.

The social environment has a large role in shaping personality or influencing one's behavior. The social environment includes the family environment, peers and neighbors. The family environment is a miniature of society and its life. The things that need to be considered in the family environment are social status, economy, family atmosphere, parenting and family support. The family is responsible for the formation of children's behavior. The child's actions or behavior should be the responsibility of parents. Thus, if a child commits an act that violates the rules, the parents will be blamed. Laning (2008) argues that these basics are the standard so parents are often blamed if there are children who behave not according to the rules. In line with Laning, Yusuf (2006), said that families can also be a cause of the emergence of juvenile and juvenile delinquency. A child who is raised in a broken home family, for example, parents' attention will be greatly reduced, the parent-child relationship is not harmonious, religious values are so weak that the child's personality development will be distorted so it is difficult to adjust to their environment. Furthermore, children will experience difficult things and can fall into the association of bad children. Laning (2008) also argues that children who lack attention and affection from parents will feel insecure because they have lost their place of refuge. One day, children will vent revenge in the form of anti-social attitudes toward their environment. Children begin to disappear from the house, steal, lie, to attract the attention of their parents. Children begin to develop negative reactions to gain life satisfaction by committing crimes.

The next social environment that interacts and influences children is peers. The influence of whether or not a child in a peer group depends on the child's perception of the group. This is because children's perceptions of peer groups will determine the decisions taken by children which in turn will affect the high and low tendency of delinquency in children. Through interpersonal relationships with peers, children learn to judge themselves and their position in groups. For children who lack love or guidance from their parents, they are usually less selective in choosing friends so they are easily influenced by the attitude and behavior of their group. The role of peers in adolescent relationships becomes very influential. This is in line with the characteristics of adolescents, one of which is increased interest in establishing friendships and participation in groups. Peer groups are also a community of learning places where social roles and standards are formed. 
The next environment that influences children's behavior is the neighboring environment. Neighbors are people who physically live close to each other. In the order of living in a society, neighbors are the second environment after the family. The neighboring environment consist of various social classes, ethnic groups, different religious groups. Thus, social interaction in society is strongly influenced by neighboring relationships. A bad neighborhood can also affect a child's behavior in committing a crime.

The next factor that influences children/adolescents is sociocultural values. According to Taylor, culture is a complex totality that includes knowledge, language, belief, art, law, morals, customs and traditions. In other words, culture is the product of work and human intention which is developed as part of human civilization which is used as a guide to do something. Culture can last long in the midst of human civilization because it has values that remain valid and universal such as norms, customs, traditions, ideas, technology, art, and objects created by humans. However, culture will continue to experience changes and developments in accordance with the progress achieved by humans.

The sociocultural aspect is the aspect that is closest to everyday human life. Every human activity is almost never separated from the sociocultural element because most of it is done in groups. The social environment plays a role in preparing individuals so that later they can adjust to the community where they are. This is because of the community has a diverse life order, the interests of one individual are not the same as the other individuals.

In society, each individual has their own interests and goals in life. Thus, rules are needed to regulate so that these various interests can be met properly and not harm one another. On the other hand, the community always experiences development. Every society, even the most traditional, fast or long will change. This is also influenced by the development of increasingly complex human needs accompanied by science and technology that is so rapid. The social aspects of human culture continue to develop, from life that tends to traditional to more modern life. Although, technological advances sometimes make sociocultural values increasingly eroded. The progress of communication technology, for example, makes social interaction diminish. This, in turn, has an impact on the increasingly tenuous social relations in society.

Based on the above explanation, it can be concluded that there are various sociocultural aspects that influence human behavior, namely the social environment and sociocultural values. In the context of the behavior of children conflict with law they are family, peers, neighbors and the surrounding community.

\section{Research Method}

This study uses qualitative design because it can dig deep information using various data sources so that it can be used to analyze problems more comprehensively. This research was conducted in the city of Bengkulu, North Bengkulu Regency Seluma Regency, and Kepahyang Regency. This location was chosen because in the three regions most of cases of children in conflict with law occurred. The four location is located scattered and has different sociocultural values. Environmental diversity and sociocultural values make it possible to understand the cases more comprehensively. The informants were children in conflict with law, parents, neighbors, fellow friends, religious leaders, community leaders, and social workers. The social worker also became an informant because has a role in handling the cases originating from various regions in the province of Bengkulu. Data were collected by using in-depth interview, field notes, observation, and documentation study.

\section{Research Result}

Based on the results of the study, it was found that all $\mathrm{ABH}$ parents had low education, namely elementary or middle school. The work of almost all parents is farmers or odd jobs. They spend their time working to make a living, from the morning and going home late at night .. This causes a very 
lack of time to interact with children. As happened in the case of NL, VJ, FR, and SN. The four are children who are victims of rape where the culprit is the son of his own neighbor. Ironically, they live around the perpetrator's house. When this research was conducted, according to information from social workers, the perpetrators' families did not live in the village anymore. The offender's family decided to sell his house and move to another place while the perpetrators were rehabilitated at the Apus Bambu LPKS Jakarta. When the incident occurred, the parents of the victims were not at home. Every day, parents usually leave their children who are considered to be able to take care of themselves to others who are trusted, such as a grandmother or close neighbors. Parents usually stay in the garden for about 1 week and then go home. The wrong association makes the perpetrator who often sees pornographic videos with his friends motivated to commit immoral acts that violate the law.

Most of the cases studied showed that both victims and perpetrators usually did not get enough attention and affection from their parents. This wrong parenting results in uncontrolled children's behavior As stated by Shanti (in Astuti, 2011) that parenting is a pattern of interaction between parents and children. In these interactions, it can be seen how parents set rules, teach values and norms, give attention and affection and foster attitudes and good behavior so that they can be an example for their children. On the other hand, according to Prasasti (2010) families that are not intact can cause antisocial behavior and behavior. The SI case, which has repeatedly committed rape of children is one example where children from broken home families have a negative impact on children's development and behavior. His family cannot provide a good education so he is unable to adapt to various social rules that apply in social life. Therefore, the family is said to be a forum for forming children's behavior. Good or bad behavior of children, strongly influenced by family and children's behavior is the responsibility of their parents. This provision has been entrenched in social life. The influence of the environment, especially the social environment is not only in the form of positive things but also negative things. The negative effects due to the influence of the social environment one of which is the multiplication of personalities that deviate from social rules which then manifests in the form of juvenile delinquency, low sense of responsibility, etc. including the case of children who are faced with the law.

Thus, family functions are so important, as the smallest environment that should be responsible for educating children so that they are able to adjust to various social rules and norms in the community later. As stated by Laning (2008) that children need love, protection, attention, and security. It is the family that is expected to be able to provide all that. The family is the smallest unit of society which is a place to educate children so that they are able to carry out their roles and responsibilities when they are already in the midst of a society in a broad sense. A family is a place where children can pour out their hearts and discuss the problems they face. In the family, there is a sense of compassion that is based on a very strong inner bond so that every family member feels comfortable in it. Furthermore, parents are expected to provide religious education and socialize various rules, values, and norms that apply in the community so that their children's behavior is in accordance with the rules.

The next socio-cultural factor that interacts in the case of children facing the law is wrong association accompanied by the negative impact of using technology. As is known, that children, especially those who begin to move teenagers often spend more time with people outside their families. This is in line with the characteristics of adolescents, one of which is increased interest in establishing friendships and participation in groups. The desire and encouragement to try things and new experiences also greatly influence the behavior of adolescents. Therefore, wrong relationships will have a negative effect. In this study, all the actors said that they were compelled to commit immoral acts that violated the law because they wanted to try things as they saw them. According to the confession of the perpetrators, they did it after seeing pornographic videos seen through cell phones with their friends. Lack of supervision from parents, lack of religious education, failure of educating parents and the absence of exemplary examples that should be imitated make teenagers fall prey to crime so that cases of children confronting the law occur. To cover up guilt over the lack of time to interact with children, many parents in the city and in the village provide mobile phones for their children. However, the lack of control accompanied by the weakness of religious values, especially in the family, made this backfire for the family and also the community. There are many cases of juvenile delinquency such as rape, molestation, fighting, theft and other acts of violence. 
In terms of cultural aspects, based on interviews with religious and community leaders, it was known that the increased of children in conflict with law due to changing in values and norms that applied in social life. Gradually, the values of local wisdom are being abandoned. In one of the research locations, namely in the Regency of Kepahyang, in ancient times there was local wisdom called "alms of earth density or clean hamlets". This activity is in the form of activities whose purpose is intended for the safety of the village. At certain times, usually once a year, all community members hold a "village salvation" event. In this activity, the residents collect food ingredients which are then cooked together. Every citizen gives donations as much as possible, both in the form of food and help. A black colored goat, called "great goat", was prepared.. After the meal is ready to be eaten, a person who is "harvested", usually a traditional leader/community leader, a respected religious leader, will lead the event. Before the joint meal event began, the community led by the custom leader prayed together for the safety of their residents and villages. Children are not allowed to eat food for this salvation and those who cook the food must be old people who don't have small children anymore. This local wisdom makes a sense of togetherness and psychological bonds among fellow citizens . Kinship values are well maintained. The positive impact is the very low behavior that deviates from applicable rules and social norms. This is because people feel that they are brothers. Thus, all citizens feel that order must be maintained because it is their shared property and responsibility. In addition, customary sanctions relating to sexual violations, namely "village washing" are strictly enforced. Village washing is a term that is imposed on those who violate moral norms such as adultery. A person who is sanctioned must slaughter a goat and feed the villagers and wine around the village as a ransom to clean the village from despicable acts. According to community leaders, the charity of the earth's density for 10 years has never been carried out again. Slowly this made the bond of togetherness among the citizens began to stretch. The next result is social control become weaker because each citizen begin do no care to various events that occur around him and in the wider community.

In North Bengkulu Regency also applies village washing customs to clean the village from immoral actions. The heaviest sanctions other than washing the village are the actor and their families must leave or move from the village. The influence of religious and community leaders, the spread of immoral cases, has caused changes in cultural and religious values. Around 1976, there were still many religious schools. The community used to recite in their homes. Regular recitation of mothers and fathers. In other words, the nuances of religion are felt to color the life and behavior of the village people. Judging from the association of young children, there is strong social control. If there are women and men sitting together, then they will be accompanied by a host who is in charge of watching over their actions. In ancient times, men should not hold the hand of a woman who was not her husband. If this is violated, it will be subject to financial penalties and customary sanctions "as cold as betel leaves". Adolescent girls usually do not leave the house and even if they leave the house in polite and accompanied clothing.

After private schools existed, the religious schools slowly closed. Children were not accustomed to reciting anymore, as well as recitation of mothers and fathers were no longer held. Teenage girls start going out. Long and polite clothes began to be abandoned and changed into clothes that were rather open. In 1978, music began to enter this area. In every celebration, for example, marriage often starts using music/bands/ organs which usually starts from noon to midnight. The negative effect is that it is used by young men and women to gather and stay up late at night. In fact, wedding events are often used as an arena to find a partner or dating. At first, this got a strong rebuke from the old people. But with the passage of time, the rebuke was ignored by young people so that over time this behavior was omitted. The impact is the frequent occurrence of association which tends not to negate social norms and religious norms.

In the past, if anyone commits immoral actions, they will be directly punished by being paraded around the village and obliged to do village washing. However, now this deed began rarely to be considered If there were women who are pregnant before marriage, the family is not too restless. Because it is considered "normal". Sanctions for village washing are still there, but they are rarely done because if there are teenagers or unmarried women who are pregnant, they are usually secretly married by their families. 
In addition, the shifting in value also occurs in social status and relations. If in the past people were respected because of religious knowledge or were community leaders who could be emulated, now that value had changed. At present people are respected if they have a lot of wealth . Kinship interactions began to stretch and social relations began to lead to material or money. According to religious leaders, it is now very difficult to find formal and informal leaders whose behavior could be imitated. On the contrary, what often happens is the behavior of leaders who cannot be emulated and far from religious guidance. The absence of exemplary figures, the fading of social values, norms and good religion make the social control weaker. This is also the reason for the rise of juvenile delinquency cases including children in conflict with law.

\section{Conclusion}

There are various sociocultural factors interacting in the case of children facing the law. These factors are low education which results in a lack of parental knowledge in educating their children. Low education makes most people only work as farmers or laborers, so most of the time is spent working outside the home. This results in a lack of interaction with their children. Parenting and wrong relationships, accompanied by negative effects of technology make children encouraged to commit criminal actions. On the other hand, the lack of knowledge and low compliance in carrying out religious guidance and the shifting of social, cultural and religious values and norms made social control weak. These factors are what encourage the increase of cases of children dealing with the law.

Based on the results of the study, the researcher recommends the following:

i. Optimizing family functions and increasing family resilience by providing counseling or formal and religious education to parents and their children

ii. Re-develop positive sociocultural values/norms in the community by optimizing the role of legal institutions and traditional institutions as well.

iii. Increasing the concern of formal/informal leaders to be a good leaders in the community

iv. Providing information to the public about the negative impact of technology.

\section{References}

Astuti, Mulia. (2011). Children are faced with the law in terms of their upbringing in the family https: //media.neliti.com/media/publications/52796-10-anak-berhadap-dengan-hukum-ditinjau-daripola asuh dalam-keluarga-pdf. Journal of Information, Volume 16 no April 1, 2011.

Clemes Harris (2001). Teach discipline to children. Jakarta. Main Partner

Dalyono, M. (1997). Educational psychology . Jakarta. Rineka Cipta.

Laning, Vina Dwi (2008). Juvenile delinquency and prevention . Klaten. Cemapaka Putih.

Soetodjo, Wagiati (2006). Child criminal law . Bandung. Refika Aditama.

Ministry of Social Affairs RI (2014). Technical guidelines for social protection and rehabilitation of children are faced with the law in social welfare organizing institutions.

Ministry of Social Affairs RI (2015). Training module for handling children facing the law for social workers. 